\title{
THE ADAM-CHRIST TYPOLOGY IN PAUL AND ITS DEVELOPMENT IN THE EARLY CHURCH FATHERS
}

\author{
John VanMaaren
}

\begin{abstract}
Summary
This article examines the development of the Adam-Christ typology in the early church. It begins by outlining the characteristics of typology and considering Paul's use of the Adam-Christ typology. It then looks at the Adam-Christ typology in Irenaeus, Hippolytus, Origen, Methodius, Augustine and Cyril of Alexandria. Each of these is compared with Paul. For Paul, it is Christ's death and resurrection that correspond to Adam's sin. The church fathers expand Paul's typology and these expansions eventually come to overshadow the main point of correspondence for Paul, Christ's death and resurrection.
\end{abstract}

\section{Introduction}

One way the New Testament writers understood the person and work of Christ was through the person and work of the first man, Adam. Christ was pictured as the second Adam who succeeded where Adam failed. This typological interpretation of the Old Testament was a common way New Testament writers read the Old Testament in which they found 'types' of Christ throughout the Old Testament that prefigured different aspects of Jesus' life, death and resurrection. Because Paul's writings contain the only explicit Adam-Christ typology in the New Testament, this paper will compare his use of the Adam-Christ typology with the early church fathers' use in the writings of Irenaeus, Hippolytus, Origen, Methodius, Augustine and Cyril of 
Alexandria. ${ }^{1}$ This comparison will show a gradual development away from Paul's understanding of the Adam-Christ typology, which finds its correspondence between Adam's sin and Christ's sacrificial death, and toward a typology that finds its correspondence between Adam's sinful life and Christ's sinless life.

\section{A Genuine New Testament Typology}

In his seminal work on typology, Typos: The Typological Interpretation of the Old Testament in the New, Leonhard Goppelt defined typology as 'a prefiguration in a different stage of redemptive history that indicates the outline or essential features of the future reality and that loses its own significance when that reality appears'. ${ }^{2}$ This seventy year-old definition notes three aspects of correspondence between type and antitype that have retained general scholarly consensus. First, the correspondence must be historical. It is a 'theological interpretation of history' in the same way the Old Testament interpreted history theologically, but done after the further revelation given in Christ. ${ }^{3}$ In this way it differs from allegory - correspondence between words understood as inspired symbols removed from a historical context - by pointing out correspondences in God's historical dealings with man. ${ }^{4}$ Second, the points of correspondence must be in essential rather than accidental features. France helpfully redefined 'essential' as 'theological' and noted that a typological correspondence that was not theological removed the basic assumption of typological interpretation, the perception of a constant principle in the working of God. ${ }^{5}$ Third, the correspondence is divinely ordained. While there is a greater dissenting scholarly voice here, Ellis correctly noted that the significance of Old Testament types for New Testament writers was

\footnotetext{
1 Tertullian also makes use of an Adam-Christ typology in On the Soul (44.10), but very briefly.

2 Leonhard Goppelt, Typos: The Typological Interpretation of the Old Testament in the New (Grand Rapids: Eerdmans, 1982; tr. from German, 1939): 177.

3 Francis Foulkes, 'The Acts of God: A Study on the Basis of Typology in the Old Testament' in The Right Doctrine from the Wrong Text?: Essays on the Use of the Old Testament in the New, ed. G. K. Beale (Grand Rapids: Baker, 1994): 366.

4 Foulkes, 'Acts of God', 367.

5 R. T. France, Jesus and the Old Testament: His Application of Old Testament Passages to Himself and to His Mission (Downers Grove: Intervarsity, 1971): 41.
} 
specifically their locus in God's plan of redemption. ${ }^{6}$ Statements like Paul's in 1 Corinthians 10:117 show that the New Testament writers understood typology to be divinely ordained and suggest that the dissenting scholars may have confused the reality of a type's divine ordination with the early church's belief in the same.

In addition to the typological correspondence's being historical, theological and divinely ordained, Goppelt noted that there must be a heightening. The antitype fulfils the type yet exceeds it in some essential way. ${ }^{8}$ Foulkes noted that 'the difference lies in the incomplete and preparatory nature of the type compared with the completeness and finality of the antitype'.

It is also important to understand what typology is not. It has already been noted that typology is different from allegory because it is grounded in history. In addition, typology is not prediction-fulfilment. The type is neither a prediction nor the antitype a fulfilment of a prediction. While Beale noted that in some cases of typology the Old Testament writer appeared to be pointing to the future, this is rarely the case. ${ }^{10}$ Lampe helpfully termed the type a 'mystery', secretly placed in history by God only to be revealed in Christ. ${ }^{11}$ Typology is also not a form of exegesis because it seeks to do more than understand the text in its original context and therefore cannot be systematised. Foulke acknowledged that typology reads a meaning into the text that is foreign, but was quick to point out it does not introduce a foreign principle into the text. ${ }^{12}$ It interprets the Old Testament event in its literal context then uses this to point to how God has dealt with men in Christ.

6 E. Earle Ellis, Paul's Use of the Old Testament (Ann Arbor, MI: Baker, 1957): 127.

7 'These things happened to them as examples ( warnings for us, on whom the fulfillment of the ages has come' (NIV).

8 Goppelt, Typos, 177.

9 Foulkes, 'Acts of God', 367.

10 G. K. Beale, A New Testament Biblical Theology: The Unfolding of the Old Testament in the New (Grand Rapids: Baker, 2011): 956.

11 G. W. H. Lampe, 'The Reasonableness of Typology' in Essays on Typology (Naperville, IL: Allenson, 1957): 29.

12 Foulkes, 'Acts of God', 369-70. 


\section{The Adam-Christ Typology in Paul}

Paul's understanding of Adam is grounded in Genesis 1-3 and influenced by post biblical Jewish reflection on Adam. While there is little reflection of Genesis 3 as an explanation for human sinfulness in the Jewish scriptural tradition, by the First Century this account had become a prominent way of explaining the human condition. ${ }^{13}$ Regarding the Adam-Christ typology, the amount of variation and the diversity of Scripture quotations suggest Paul was not the originator. ${ }^{14}$ It distances itself from most understandings of a primal man in antiquity by its lack of speculative and metaphysical details..$^{15}$

While elements of the Adam-Christ comparison appear elsewhere in Paul, the Adam-Christ typology is most clearly outlined in two passages. ${ }^{16}$ The most extended is Romans 5:12-21, but the germ of this passage is found in 1 Corinthians 15 , which will be addressed first. ${ }^{17}$ In neither passage is Christology the focus. Rather, Paul employed the Adam-Christ typology to argue for the reality of a bodily resurrection of the dead in 1 Corinthians, and then in Romans to show the universal validity of freedom from death.

In 1 Corinthians 15 the Adam-Christ typology appeared twice in Paul's defence of a general bodily resurrection of believers. It first appeared in 15:20-23 where Paul appealed to the reality of Christ's resurrection to argue that believers will also rise. In verse 20 Paul calls Christ the 'firstfruits of those who have fallen asleep'. Barrett notes that Paul used 'firstfruits' to mean 'the first installment of the crop which foreshadows and pledges the ultimate offering of the whole'. ${ }^{18}$ In this way Christ's resurrection guarantees the believer's resurrection. The reason Christ could be the second Adam was because of his shared

13 James D. G. Dunn, The Theology of Paul the Apostle (Grand Rapids: Eerdmans, 1998): 86. Romans contains strong parallels to the Wisdom of Solomon, of which Paul was certainly familiar. Also see Jubilees 3 .

14 Ernst Käsemann, Commentary on Romans (Grand Rapids: Eerdmans, 1980; tr. from German, 1980): 144.

15 Egon Brandenburger, Adam und Christus: exegetisch-religionsgeschichtliche Untersuchung zu Röm. 5, 12-21 (1. Kor. 15) (Neukirchen: Neukirchener Verlag, 1962): 159.

16 See for example Rom. 8:1; 13:14; 1 Cor. 1:30; 2 Cor. 2:17; Gal. 3:16; Eph. 1:13; Col. 1:28.

17 Hans Conzelmann, 1 Corinthians: A Commentary (Hermeneia, 60; Philadelphia: Fortress Press, 1975): 287.

18 C. K. Barrett, A Commentary on the First Epistle to the Corinthians (Black's New Testament Commentaries, 7; London: A \& C Black, 1971): 350. 
humanity (15:21). Prefiguration is indicated by the initial rá $\rho$ that links verse 21 with the previous verse and makes human nature a necessary prerequisite of Christ's role as the second Adam. ${ }^{19}$ The point of correspondence was the universal scope of the consequences of their action in verse 22: 'For as in Adam all die, so in Christ all will be made alive.' Commentators are generally agreed the second 'all' must refer to all those in Christ rather than all humanity and this is the only reading that fits the context. ${ }^{20}$ Paul argued for the certainty of the resurrection of those already in Christ rather than the universality of participation in Christ. The Adam-Christ typology allowed Paul to argue from the certainty of death for those in Adam to the certainty of a resurrection for those in Christ. Typological heightening is present in the qualitative difference between death and life. ${ }^{21}$

Paul again employed the typological relationship in 15:44-49 where he used it to argue for a bodily resurrection from the dead. Here there are two points of correspondence and both involve heightening. First, the origin of both involved a new type of life, but while the first Adam

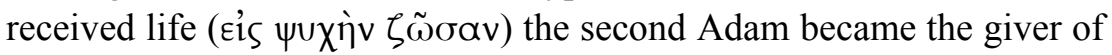

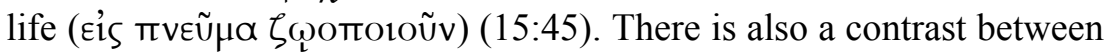
the first Adam as a 'being' ( $\psi \cup \chi \eta \dot{v}$ ) and the second Adam as a 'Spirit' $(\pi v \varepsilon \tilde{u} \mu \alpha)$. Second, the 'descendants' of each share in the likeness of their progenitor, but while the first Adam was 'from the dust of the

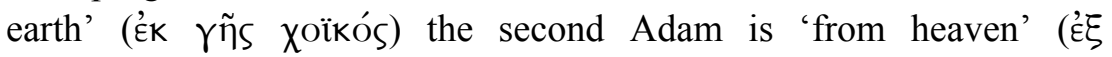
oúpavoũ) (15:47). Paul's addition of 'first' to 'man' in his free quotation of Genesis 2:7 in 15:45 indicates his understanding of Adam as a divinely ordained prefiguration of Christ. ${ }^{22}$

A long tradition has identified 'from heaven' in verse 47 with Christ's pre-existence and understood this second contrast to refer to Adam and Christ's origin. For the following reasons it is better to understand 'from heaven' to refer to Christ's present heavenly resurrected state: (1) The context is concerned with Christ's present

\footnotetext{
19 Beale, Biblical Theology, 440.

20 See especially W. V. Crockett, 'The Ultimate Restoration of All Mankind: 1 Corinthians 15:22' in Studia Biblica 1978: III. Papers on Paul and Other New Testament Authors (Sheffield: Sheffield, 1980): 83-87. William Orr, 1 Corinthians (ABS 32; Garden City, NY: Doubleday, 1976): 332; Barrett, First Epistle to the Corinthians, 352; Gordon Fee, The First Epistle to the Corinthians (NICNT 39; Grand Rapids: Eerdmans, 1987): 750. Conzelmann, 1 Corinthians, 269.

21 Conzelmann, 1 Corinthians, 268.

22 Beale, Biblical Theology, 440.
} 
heavenly state as a guarantee of the believer's future heavenly existence and any discussion of origins is foreign to the passage. (2) The reason Paul identified Christ as the one 'from heaven' was that believers share his heavenly existence. Paul's point is that believers will share in the resurrection, not that they were also pre-existent. (3) If 'from heaven' referred to Christ's pre-existence, it contradicts the point made in the previous verse that the spiritual comes second. ${ }^{23}$ It is therefore better to understand 'from heaven' to refer to Christ's postresurrection body rather than pre-existence.

The Adam-Christ typology in Romans 5:12-21 is unique because of the degree to which the disjunction between the type and antitype is emphasised. ${ }^{24}$ This has led some commentators to conclude it is not typology, but Cranfield correctly pointed out that the contrast is only significant because of their typological correspondence. ${ }^{25}$ In addition, the use of 'type' (тúnos) in 5:14 clearly indicates typology. Scroggs argued the contrast is really between God's grace in Christ and man's $\sin .{ }^{26}$ The Adam-Christ typology is used to assure the Roman Christians of the infinite superiority of God's grace in Christ compared with his earlier wrath.

There are two points of correspondence between Adam and Christ. Both were single individuals: 'the one man' (тoũ Évós) and 'the one

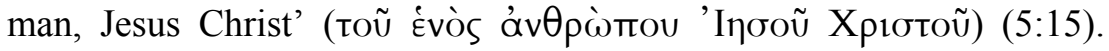
Each did one act that had an effect on the rest of humanity: 'Consequently, just as the result of one trespass was condemnation for all men, so also the result of one act of righteousness was justification that brings life for all men' $(5: 18) .{ }^{27}$ As in the Corinthians passage, the 'all men' that are justified must refer to all men who are part of the second Adam. Typological heightening is clearly seen when it is remembered this is a contrast between God's grace and his wrath. In verse 15 the infinite superiority of God's grace is shown because it is not lessened as a result of the universal death that stemmed from the one sin, but only becomes greater. In verse 16 the same point is made

23 Fee, The First Epistle to the Corinthians, 792; Conzelmann, 1 Corinthians, 287.

24 Steve Moyise, Paul and Scripture (Grand Rapids: Baker, 2010): 25.

25 C. E. B. Cranfield, A Critical and Exegetical Commentary on the Epistle to the Romans (ICC, 1; Edinburgh: T\&T Clark, 2002): 295.

26 Robin Scroggs, The Last Adam: A Study in Pauline Anthropology (Philadelphia: Fortress Press, 1966): 81.

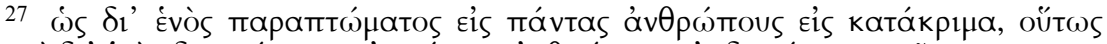

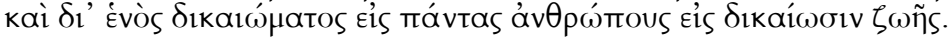


by noting that God's grace followed a greater number of sins and brought a qualitatively better result. In verse 17, Paul argues for the infinitely greater and more assured reign of those in Christ on the basis of the universal reign of death over those in Adam. Many commentators understand the obedience of Christ in verse 19 to refer to Christ's sinless life. ${ }^{28}$ While this must remain a possibility, the parallelism with verse 18 , which clearly refers to Christ's death, and the theme of justification suggest that Paul used 'obedience' to refer specifically to Christ's 'subjective disposition in the face of death' ${ }^{29}$

This summary of 1 Corinthians 15 and Romans 5 has shown that Paul understood Adam to be a type of Christ because he prefigured Christ as one man who did one action that had consequences for all those who participated in his image. While 'heavenly' in 1 Corinthians 15:47 can be read to refer to Christ's pre-existence, and 'obedience' in Romans 5:19 can be understood to refer to Christ's sinless life, in both cases the better contextual reading understands these to refer respectively to the resurrected Christ and Christ's obedience in death.

\section{The Development of the Adam-Christ Typology in the Church Fathers}

\subsection{Irenaeus}

The first extant writing of the early church to make use of the AdamChrist typology was by Irenaeus in his anti-gnostic polemic Adversus Haereses (c. 180). Typology, as the tool that enabled Irenaeus to be the first to systematically join the Old and New Testaments, plays a major role in his writings. ${ }^{30}$ Regarding the Adam-Christ typology, Jean Daniélou writes that Irenaeus 'integrates into a theological scheme the scattered remarks of St. Paul, attempting a further precision and systematization'. ${ }^{31}$ Irenaeus's use of the Adam-Christ typology is

28 Käsemann, Romans, 157; Cranfield, Romans, 291; Joseph Fitzmyer, Romans (ABD, 33; New York: Doubleday, 1993): 421.

29 Brendan Byrne, Romans (Sacra Pagina, 6; Collegeville, MN: Liturgical Press, 1996): 181. See also Robert Jewett, Romans: A Commentary (Hermeneia, 59; Minneapolis: Fortress Press, 2007): 386; James D. G. Dunn, Romans (Word, 38; Nashville: Thomas Nelson, 1988): 284.

30 Eric Osborn, Irenaeus of Lyons (Cambridge: Cambridge, 2001): 184.

31 Jean Daniélou, From Shadows to Reality: Studies in the Typology of the Fathers (Westminster: Newman Press, 1960): 31. 
closely connected to his well-known idea of recapitulation taken from Ephesians. For Irenaeus, Christ 'recapitulates' the work of Adam by undoing his sin by his work on the cross and succeeding where Adam failed. He understands Christ to recapitulate the whole creation, not just Adam. ${ }^{32}$ Woollcombe notes that this is not a new idea, but is entrenched in Old Testament prophecy where it is seen most clearly in the way Ezekiel's temple was a recapitulation of Solomon's temple. ${ }^{33}$

Irenaeus' most extensive interaction with the Adam-Christ typology was in the third book of Adversus Haereses. While Irenaeus noted in chapter 16 that proofs showing Jesus to be the Christ are written throughout the Old Testament, he did not mention the Adam-Christ typology until chapter 18 . Here he argued against the belief that Jesus and Christ are two distinct beings. In support of the doctrine that Jesus existed prior to his life on earth Irenaeus noted that Jesus' purpose in coming to earth was to begin anew the long line of human beings and thereby bring salvation. ${ }^{34}$ The purpose of this coming was to recover what was lost in Adam. In this same chapter he included three quotations from 1 Corinthians 15 and Romans 5. In most cases where Irenaeus used the Adam-Christ typology, he also quoted the two Pauline passages, showing that his typology was derived from and highly dependent on Paul. Toward the end of this chapter Irenaeus returned to this comparison and, paraphrasing Romans 5:19, wrote: 'For as by the disobedience of the one man who was originally molded from virgin soil, the many were made sinners, and forfeited life; so was it necessary that, by the obedience of the one man, who was originally born from a virgin, many should be justified and receive salvation. ${ }^{35}$ Here Irenaeus expanded on Paul's typology and added another point of comparison: As Adam was moulded from virgin soil, so Christ was

\footnotetext{
32 Robert L. Wilkin, Judaism and the Early Christian Mind: A Study of Cyril of Alexandria's Exegesis and Theology (New Haven: Yale, 1971): 97.

33 K. J. Woollcombe, 'The Biblical Origins and Patristic Development of Typology' in Essays on Typology (Naperville, IL: Allenson, 1957): 39-75, esp. 43.

34 Irenaeus, Haer., 3.18.1; Alexander Roberts, trans., Against Heresy (ANF 1; Ann Arbor, MI: Cushing Mallow, 1975): 446; Adelin Rousseau, trans., Contre les heresies (SC 211; Paris: Les Éditions du Cerf, 2002-06): 367.

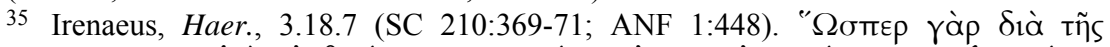

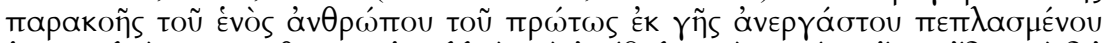

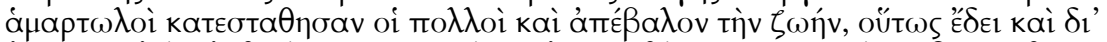

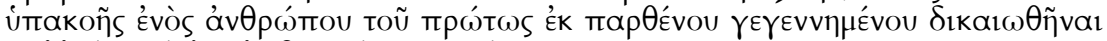

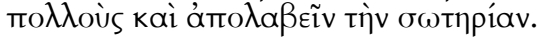


born of a virgin. For Irenaeus, this point of correspondence guarantees Christ is of the same flesh as Adam. ${ }^{36}$

In chapter 21, the Adam-Christ typology appeared again. Here Irenaeus argued for the importance of the virgin birth. Toward the end of the chapter, he returned to the comparison between the virgin soil from which Adam was created, and the virgin birth of Christ. One further aspect of this comparison was added here. Irenaeus wrote: 'But if the former was taken from the dust, and God was his maker, it was incumbent that the latter also, making a recapitulation in Himself, should be formed as man by God, to have an analogy with the former as respects His origin.' ${ }^{37}$ Just as Adam had no earthly father, but was formed by God, so Jesus had no earthly father, but his humanity was formed by God. Here Irenaeus is clearly influenced by 'dust' in 1 Corinthians 15:47, but moves in a different direction than Paul. Where Paul contrasts Adam's earthly nature with Christ's heavenly (resurrected) nature, Irenaeus makes a positive comparison between Adam's earthly nature and the necessity of Christ also being made man.

Irenaeus also made use of a Mary-Eve typology in the following chapter to further develop his argument for the virgin birth. Although this represents a distinct typology, probably an interpretation of Luke 1:39 in light of Genesis 3, it is still worth noting because of its close proximity. ${ }^{38}$ The parallel is between Mary, who as a virgin obeyed God, and Eve, who as a virgin did not obey. ${ }^{39}$ Irenaeus argued that Eve must have been a virgin because, 'they were both naked, and were not ashamed' (Genesis 2:25), and they had no understanding of procreation.

There is one further correspondence that Irenaeus developed in his Adam-Christ typology. To understand this it is necessary to quote Irenaeus' treatment in full.

But according to the cycle and progress of the days, after which one is termed first, another second, and another third, if anybody seeks diligently to learn upon what day out of the seven it was that Adam died,

36 Denis Minns, Irenaeus (Washington DC: Georgetown University Press, 1994): 88.

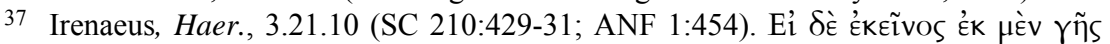

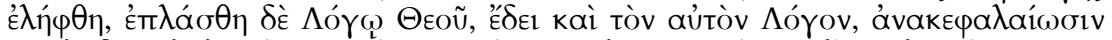

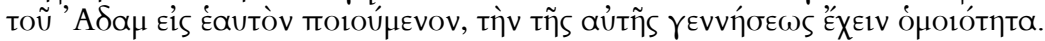

38 Bertrand Margerie, An Introduction to the History of Exegesis Vol. 1: The Greek Fathers (Petersham, MA: Saint Bede's Publications, 1994): 62.

39 Irenaeus, Haer., 3:22:4 (SC 210:439-41; ANF 1:455). 
he will find it by examining the dispensation of the Lord. For by summing up in Himself the whole human race from the beginning to the end, He has also summed up its death. From this it is clear that the Lord suffered death, in obedience to His Father, upon that day on which Adam died while he disobeyed God. Now he died on the same day in which he did eat. For God said, 'In that day on which ye eat of it, ye shall die by death'. The Lord, therefore, recapitulating in Himself this day, underwent His sufferings upon the sixth day of the creation, on which day man was created; thus granting him a second creation by means of His passion, which is that [creation] out of death. ${ }^{40}$

The logic of this passage is elusive, but must be outlined as follows. Irenaeus began by claiming it is possible to discover what day Adam died by examining the dispensation of the Lord. Because Christ summed up the whole human race into himself, including death, it follows that the day Christ was obedient to his father must be the same day (of the week) that Adam was disobedient. It is clear that on the same day they ate from the tree they also died, because this was what God had promised them. Since Christ died on the sixth day, Adam also died on the sixth day of creation. Adam sinned and died the same day he was created. Therefore Christ's death corresponds not only to Adam's death, but also to the creation of man. Because of this, Christ's death was also the beginning of a new creation which recapitulates the old creation.

Irenaeus' Adam-Christ typology is closely related to Paul's. It is clear he was dependent on Paul because he rarely used the AdamChrist typology without quoting or alluding to one of the Pauline passages. Irenaeus followed Paul in that Adam is a type of Christ because he was one man whose actions had an effect on the rest of humanity.

Irenaeus' Adam-Christ typology also represents a substantial expansion. He did this by combining it with the idea of recapitulation

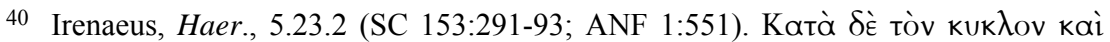

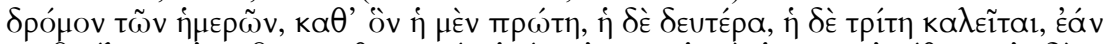

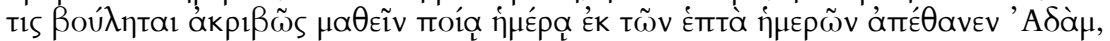

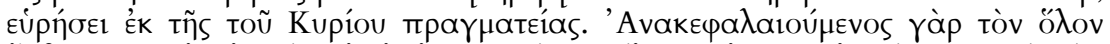

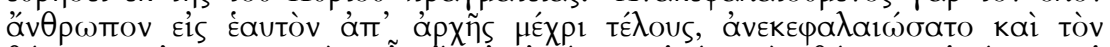

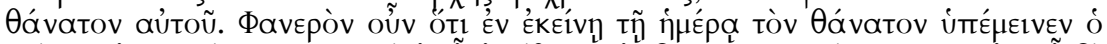

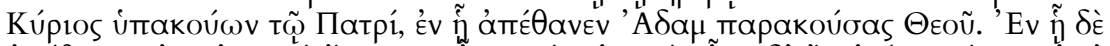

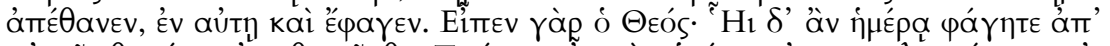

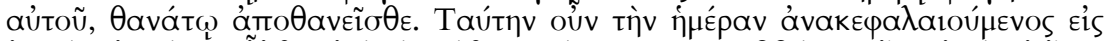

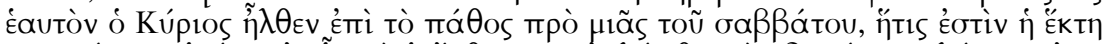

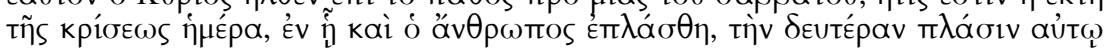

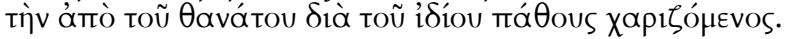


he borrowed from Ephesians, enabling him to extend the typological relation to the entire creation. Irenaeus added three additional points of correspondence. The first was the correspondence between the formation of the first and second Adam. Just as Adam was formed from virgin soil, so Christ was born of a virgin. The second and third points of correspondence are related to days of the week: the correspondence between the day of Adam's act of disobedience and the day of Christ's act of obedience and the correspondence between the day of the creation of the race that is in Adam and the day of the creation of the race that is in Christ. While the Adam-Christ typology is for Paul centred around Adam's sin and Christ's death, Irenaeus expands this to include typological correspondence with respect to origin and incidental details (days of the week).

\subsection{Hippolytus}

Hippolytus (c. 170-c. 236), writing shortly after Irenaeus, also used the Adam-Christ typology. The two passages below will serve to illustrate his usage. The first is from Contra Noetum in which Hippolytus argued against Noetus' teaching that Christ was the father in person and therefore the Father had been born, suffered and died. He writes:

So in the very same way in which he was proclaimed, he became present as well, and manifested himself by becoming a new man from the virgin and the Holy Spirit. While, as Word, he has the heavenly element that he gets from his Father, he has the earthly element he gets by taking flesh from the old Adam through the virgin. This is he who went forth into the world and was manifested as God embodied, going forth as perfect man - for he truly became man, and not just in appearance or figuratively speaking. ${ }^{41}$

Hippolytus' metaphysical understanding of Christ is that of a combination of the Word from the heavenly nature of the father, and the flesh from the earthly nature of the old Adam, and this constituted a new man. The second passage is from the Treatise on Christ and Antichrist:

41 Hippolytus, Noet., 17.4, 5; Greek text and English translation from: Robert Buttersworth, trans., Contra Noetum (London: Heythrop, 1977): 86. ka $\theta$ ' ôv oũv

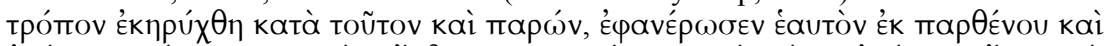

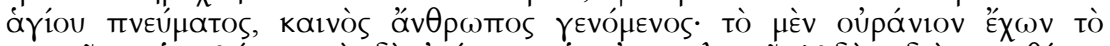

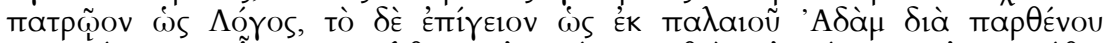

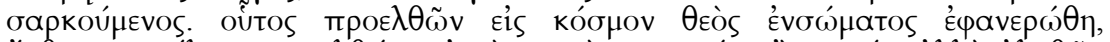

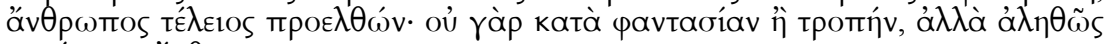

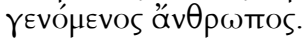


He does not hate the female on account of the woman's act of disobedience in the beginning, nor does he reject the male on account of the man's transgression. But he seeks all, and desires to save all, wishing to make all the children of God, and calling all the saints unto one perfect man. For there is also one Son (or Servant) of God, by whom we too, receiving the regeneration through the Holy Spirit, desire to come all unto one perfect and heavenly man. ${ }^{42}$

Here Hippolytus compared both the woman's disobedience and the man's transgression with the perfect man, Jesus. He contrasted the failure of the first with the perfection and newness of the second. While there is not a clear comparison between Adam and Christ, there is a clear sense in which the one who believes in Christ is transferred from the realm of Adam to the realm of Christ. As far as it can be shown, Hippolytus appears to be in basic agreement with Paul. ${ }^{43}$ While, like Irenaeus, he did not identify what Christ's obedience was, he also did not include the additional points of correspondence found in Irenaeus. Because of his limited use of the Adam-Christ typology it is not clear whether he would have agreed with Irenaeus' expanded understanding. He does have an added emphasis on the importance of the virgin birth which is not present in Paul and draws a contrast between Adam's sinful life and Christ's sinless life.

\subsection{Origen}

While Origen displayed a varied understanding of Adam, he often allegorised Adam as Christ and Eve as the church and cited Paul as a forerunner, inspired by Ephesians 5:30-32.44 Typology has an important place in Origen's (c. 185-254) understanding of the spiritual

42 Hippolytus, Antichr., 3; J. H. MacMahon, trans., Treatise on Christ and Antichrist (ANF 5; Peabody, MA: Hendrickson, 1995): 205; G. Bonwetsch and H. Achelis, eds., 'A

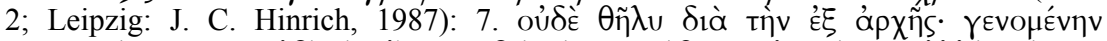

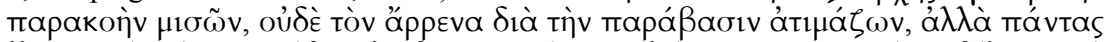

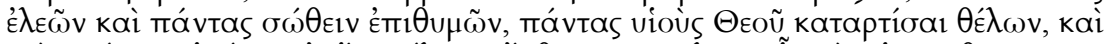

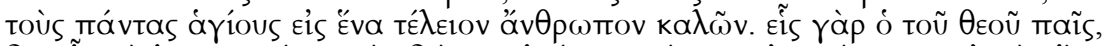
$\delta$ i' oũ kai ị

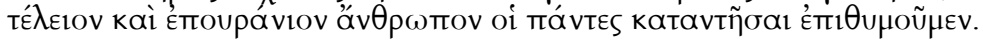

43 Maja Weyermann, 'The Typologies of Adam-Christ and Eve-Mary, and Their Relationship to One Another', Anglican Theological Review 84, no. 3 (Summer 2002): 609-626.

44 C. P. Hammel, 'Adam in Origen' in The Making of Orthodoxy: Essays in Honour of Henry Chadwick, ed. Rowan Williams (New York: Cambridge, 1989); Origen, De Principiis, 4.3.1; Paul Koetschau, ed. (GCS 5; Leipzig: J. C. Hinrich, 1913): 333. 
sense of Scripture. ${ }^{45}$ While the Adam-Christ typology is never developed into a major exegetical theme, Origen does make use of it briefly in his commentary on Romans. ${ }^{46}$ Because it is a commentary, he remained quite close to the text as he explained Paul's use and avoided allegorical excess. Origen wrote: "Adam was a "type of that which was to come", not in his being a transgressor but in the following sense: just as death had entered through him, so through the last Adam life has entered this world; and just as, through him, condemnation comes to all men, so also through Christ justification comes to all men' ${ }^{47}$ Adam was a type of Christ because he, like Christ, was a conduit through whom a change came to all men. He further explained Adam's typological relationship to Christ by the difference between a genus and a species. He wrote:

The type is similar in genus but contrary in species. For the type is similar in genus in that, just as something is diffused to very many men from the one Adam, so also something is diffused to very many men from the one Christ. But the species is contrary because the transgression which began with Adam 'made the many sinners', whereas by Christ's obedience 'many will be made righteous' 48

From this passage it is clear that Origen understood the correspondence between Adam and Christ to be one man whose actions had an effect on the rest of humanity. Where Adam transgressed, Christ was obedient. Origen, like Irenaeus and Hippolytus, did not identify whether Christ's obedience was specifically his death on the cross or the entirety of his sinless life.

Origen also was aware of the typological heightening of the antitype throughout his discussion. While commenting on Romans 5:20 he wrote: 'When [Paul] makes the comparison with each of the things

45 Margerie, History, 112.

46 Wilkin, Judaism, 96.

47 Origen, Romans, 5.1.7; Thomas P. Scheck, trans., Commentary on the Epistle to the Romans, Books 1-5 (FC 103; Washington DC: Catholic University Press, 2001): 307308; Luke Brésard, trans., Commentaire sur l'épître aux Romains (SC 539; Paris: Les Éditions du Cerf, 2010): 358: qui Adam forma futuri est, non secundum quod praeuaricatus est sed secundum hoc quod sicut per ipsum mors ita per nouissimum Adam uita ingressa est in hunc mundum, et sicut per illum in omnes homines condemnatio ita et per Christum in omnes homines iustificatio.

48 Origen, Romans, 5.2.2 (SC 539:406; FC 103:329). Per genus namque similis est forma in eo quod sicut ab uno Adam in plures homines diffunditur ita et ab uno Christo in plures homines diffunditur. Species uero contraria quod ex Adam praeuaricatione coepta peccatores constituti sunt multi; Christi uero oboedientia iusti constituentur multi. 
which seem to have occurred as a result of Adam's transgression, he shows that what has been amassed through the grace of Christ as a means of bringing healing is in opposition and much greater.' ${ }^{\prime 9}$ The consequences of Christ's work are always understood to be greater than the consequences of Adam's sin.

Origen did not expand the Adam-Christ typology beyond that outlined by Paul in Romans. He agreed with Paul that Adam is a type of Christ because he was one man whose actions had an effect on all humanity, and acknowledged the existence of typological heightening.

\subsection{Methodius}

Methodius (d. c. 311) was the first extant writer to treat the AdamChrist typology as a subject in itself and to argue for its value as an interpretative principle. ${ }^{50}$ His understanding shows significant development beyond Paul and emphasises the similarities between Adam and Christ to the extent that the differences almost disappear. ${ }^{51}$

In The Banquet of the Ten Virgins Methodius described a festival of ten virgins in the garden of Arete who praised the virtues of virginity. In the third of ten discourses, Methodius addressed a disagreement with Theophila who argued that Paul understood the story of Adam and Eve only in its natural sense in Ephesians 5:32. Methodius first asked whether it is right for Paul to compare Adam, who was cast from the garden lest he eat from the tree of life, to him who is the tree of life. ${ }^{52}$ Methodius noted that this is not the correct point of comparison and redirected the readers' attention to the true correspondence in the following chapter. He wrote: 'Christ became the very same as Adam through the descent of the Logos into Him. ${ }^{53}$ Further expounding on

\footnotetext{
49 Origen, Romans, 5.6.5 (SC 539:448-50; FC 103:347) Sicut in superioribus docuimus ubi per singula quaeque comparationem facit eorum quae ex praeuaricatione Adam accidisse uidentur aduersa et multo maiora ostendit esse quae per gratiam Christi ad remedium conlata sunt, ita et in praesenti loco cum dixisset abundasse peccatum sermone dignissimo usus est quo abundantiam uinceret et superabundantiam poneret.

50 Wilkin, Judaism, 101.

51 Wilkin, Judaism, 100.

52 Methodius, Symposium, 3.3; Herbert Musurillo, trans., Symposium: A Treatise on Chastity (ACW 27; New York: Newman, 1958): 61; Victor-Henry Debidour, Le Banquet (SC 95; Paris: Les Éditions du Cerf, 1963): 96.

53 Methodius, Symposium, 3.4 (SC 95:96-98; ACW 27:61). á $\lambda \lambda$ à kaì aútò toũto

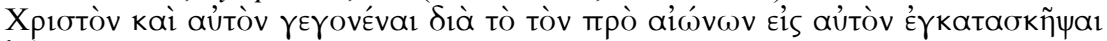

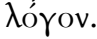


this, he wrote: 'For thus, in remodeling what was from the beginning and molding it all over again of the Virgin and the Spirit, He fashioned the same Man; just as in the beginning when the earth was virgin and untilled, God had taken dust from the earth and formed, without seed, the most rational being from it. ${ }^{\prime} 4$ The correspondence between Adam and Christ is that, just as Adam was born of untilled, virgin soil, so was Christ formed from a virgin. In the following chapter Methodius allegorised Jeremiah 18:1-4 to make this same point. In this passage Jeremiah watched as the potter, who was moulding a pot, formed the lump of clay into a different pot because the first one was flawed. Just after this the word of the Lord came to Jeremiah and told him God would do to Israel what this potter did to his clay. He understood the first flawed pot allegorically as Adam and the second refashioned pot as the second Adam. He portrayed Adam as a soft lump of clay which, before it was able to harden, was ruined by sin which ran down it like water. In contrast, God pre-hardened the second Adam, uniting the clay (i.e. human flesh) with the Word while he was still in the womb so that when he was brought forth to life he was already hardened. The point of correspondence here remains the origin of the two. This is the only correspondence Methodius acknowledged.

The comparison between Methodius and Paul shows that there is little continuity between the way these two writers understood the Adam-Christ typology. There are two significant differences between Methodius and Paul. For Paul the correspondence centred around the redeeming work of Christ's act of righteousness on the cross. For Methodius, the correspondence centred around the manner of Christ's birth. Second, for Methodius, the virgin birth was the basis on which the new humanity was created. He understood the Holy Spirit to have replaced man's sinful sperm to create Jesus as a new perfect humanity, and negate the power of $\sin$ in his humanity. In contrast, the reason for the new humanity in Paul was Jesus' resurrection from the dead, which made him the 'firstborn of the new creation' (Colossians 1:15). Christ's resurrection and the future resurrection of believers do not play important roles in his Adam-Christ typology. What appears to have been a new expansion for Irenaeus, the correspondence between Adam

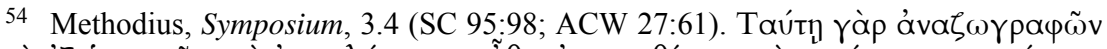

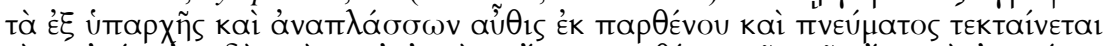

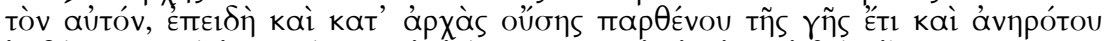

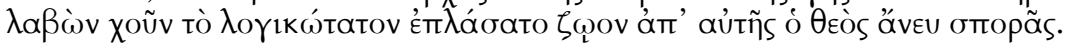


and Christ regarding origins, appears in Methodius as the primary point of correspondence while he at the same time moves away from the correspondence between Adam's sin and Christ's death.

Methodius' shift in emphasis from Christ's death and resurrection to Christ's virgin birth and sinless life is soteriologically significant. For Paul the resurrected Jesus is the firstborn of the new humanity and the one whom believers, who have the deposit of the Spirit, will eventually be made like. For Methodius, the pre-resurrected Jesus, who was born of a virgin and thereby made perfect by the union of the Holy Spirit with the virgin is the one whom new humanity will be like. Christ's death and resurrection are overshadowed by his virgin birth and speculation regarding Christ's earthly constitution.

\subsection{Augustine}

Augustine (354-430) employed the Adam-Christ typology in his formulation of original $\sin$ and repeatedly revisited it in polemics against Pelagius. He was always dependent on Paul and often addressed it while commenting on Romans $5 .{ }^{55}$ Augustine's comments on 1 John 3:8 nicely illustrate his polished use of the Adam-Christ typology.

Therefore, brothers, mark well two births, Adam and Christ. There are two men; but one of the men is a man, the other is God. Through the man-man we are sinners; through the man-God we are justified. That birth casts down to death; this birth raised up to life. That birth draws sin with it; this birth sets free from sin. For Christ came as a man precisely in order that he might undo the sins of man. ${ }^{56}$

The two births refer, not to the creation of Adam and the virgin birth of Christ, but to humanity's first birth into Adam and its second birth into Christ. As in this example, Augustine always placed the focus on the results of the first and second Adam. He did not expand on Paul's

55 Gerald Bronner, 'Adam' in Augustinus-Lexikon (Basel: Schwabe, 1994): 63-87, esp. 84 .

56 Augustine, In epistulam Iohannis ad Parthos, 4.11; John W. Rettig, trans., Tractates on the First Epistle of John (FC 92; Washington DC: Catholic University Press, 1995): 184; In Iohannis Epistulam ad Parthos Tractatus decem (Euvres de Saint Augustin 76; Paris: Institut d'Études Augustiniennes, 2008): 207-208. Ergo duas natiuitates adtendite, fratres: Adam et Christum. Duo sunt homines, sed unus ipsorum homo homo, alter ipsorum homo Deus. Per hominem hominem peccatores sumus; per hominem Deum iustificamur. Natiuitas illa deiecit ad mortem; natiuitas ista erexit ad uitam. Natiuitas illa trahit secum peccatum; natiuitas ista liberat a peccato. Ideo enim uenit Christus homo ut solueret peccata hominum. 
typology but also did not identify the actual point of correspondence between Adam and Christ. While commenting on Romans 5 Augustine stated 'This, then, is the distinction: in Adam one sin was condemned, but by the Lord many sins were forgiven.' ${ }^{57}$ This shows that for Augustine, the cross played a larger role in the Adam-Christ typology than it does for Methodius.

However, like Methodius, Augustine also shows interest in the virgin birth. While explaining how Christ was able to fulfil justice in a way that other men were not, he used the Adam-Christ typology where the comparison is between Christ and those who are in Adam and participate in original sin.

If, then, he who would fulfill [justice] is missing, how does he not fulfill? Because he has been born with the transmission of sin and death. Born of Adam, he came bringing with him what was conceived there. The first man fell; and all who were born of him came bringing from him the concupiscence of the flesh. It was necessary that another man be born who came bringing no concupiscence. A man, and a man; a man for death, and a man for life. So says the Apostle, 'For indeed by a man came death and by a man the resurrection of the dead. ${ }^{58}$

The purpose of this passage was to provide an explanation for how Christ was able to save as was no man before him. Because of this purpose Augustine did not indicate specifically whether the preresurrected Christ or the resurrected Christ is the second humanity, but the focus on the new constitution of the second Adam which lacks the first Adam's concupiscence seems to indicate that Augustine, like Methodius, understood the pre-resurrected Christ to be the second Adam.

57 Augustine, Expositio quarundam Propositionum ex Epistola ad Romanos, 29; English translation and Latin from: Paula Fredrickson, trans., Augustine on Romans: Propositions from the Epistle to the Romans, An Unfinished Commentary on the Epistle to the Romans (Texts and Translations 23; Chico, CA: Scholars, 1982): 11. Ergo haec differentia est, quod in Adam unum delictum damnatum est, a domino autem multa donata sunt.

58 Augustine, In Iohannis euangelium tractatus CXXIV, 3.12; John W. Rettig, trans., Tractates on the Gospel of John 1-10 (FC 78; Washington DC: Catholic University Press, 2000): 85; M. F. Berrouard, trans., Homilies sur l'Évangile de Saint Jean I-XVI (Euvres de Saint Augustin 71; Desclée de Brouwer, 1969): 232. Si ergo deest qui impleat, unde non implet? Quia natus cum traduce peccati et mortis. De Adam natus, traxit secum quod ibi conceptum est. Cecidit primus homo, et omnes qui de illo nati sunt de illo traxerunt concupiscentiam carnis. Oportebat ut nasceretur alius homo qui nullam traxit concupiscentiam. Homo, et homo: homo ad mortem, et homo ad vitam. Sic dicit apostolus: Quoniam quidem per hominem mors, et per hominem resurrectio mortuorum. 
That Augustine had in mind the pre-resurrected Christ is further shown by considering Augustine's explanation of Paul's statement in Romans 5:18 that 'the result of one act of righteousness was justification that brings life to all men'. He wrote: 'He said, moreover, all to condemnation through Adam, and all to justification through Christ: not, of course, that Christ removes to life all those who die in Adam; but he said "all" and "all", because, as without Adam no one goes to death, so without Christ no man to life. ${ }^{59}$ The need to explain why Paul did not mean 'all men' when he wrote 'all' disappears if the resurrected Christ is the second Adam, in which case 'all men' who are in Christ are those who receive resurrection bodies as Christ has and not every man who is in Adam.

Augustine's polished use of the Adam-Christ typology did not expand on Paul as did those of Irenaeus and Methodius, partly because he never explicitly outlined the points of correspondence. He emphasises, however, that it is Christ as a man born without the concupiscence of Adam that makes him the progenitor of a new race rather than Christ's resurrection from the dead. The typological correspondence between the creation of Adam and Christ's virgin birth which was seen in Irenaeus and Hippolytus and made the basis of the typology in Methodius was not acknowledged by Augustine. However, Augustine did echo Methodius' identification of the pre-resurrected Christ as the basis of his role as the second Adam. For Methodius, this identification was connected closely with the only point of correspondence he acknowledged: the creation of Adam and the virgin birth of Christ.

Augustine's understanding of the pre-resurrected Christ as the second Adam could indicate a processed acceptance of this new correspondence between the creation of Adam and Christ's virgin birth as the foundation for the Adam-Christ typology. However, because Augustine never explicitly stated this, it remains conjecture.

59 Augustine, De nuptiis et concupiscentia, 2.46; F. J. Thonnard, trans., Premières Polémiques Contre Julien (Euvres de Saint Augustin 23; Desclée de Brouwer, 1974): 250; Peter Holmes and Robert Ernest Wallis, trans., Anti-Pelagian Writings (NPNF 5; Peabody, MA: Hendrickson, 1994): 302. Omnes autem dixit ad condemnationem per Adam et omnes ad iustificationem per Christum, cum utique non omnes eos, qui moriuntur in Adam transferat Christus ad uitam. Sed omnes dixit atque omnes, quia sicut sine Adam nullus ad mortem, ita sine Christo nullus ad uitam; 


\subsection{Cyril of Alexandria}

Significant discussion of the Adam-Christ typology took place in the Christological controversies of the Fourth and Fifth Centuries where it was used to support the solidarity between Christ and humanity. ${ }^{60}$ Athanasius and Apollinaris both used the Adam-Christ typology to argue Christ was able to conquer death because he was the man sent from heaven. ${ }^{61}$ Because of the more extensive use of the Adam-Christ typology in this period and the similar themes in each writer, Cyril of Alexandria's view will be addressed as representative of the period. His use of the Adam-Christ typology came out most clearly in his commentary on the gospel of John and this will be examined here.

Cyril first addressed the topic while commenting on John 1:14. Referring to the first half of the verse Cyril wrote:

But profitably does he affirm that the Word dwelt in us, unveiling to us this deep Mystery also: for we were all in Christ, and the community of human nature mounted up unto His Person; since therefore was $\mathrm{He}$ named the last Adam, giving richly to the common nature all things that belong to joy and glory, even as the first Adam what pertained to corruption and dejection. ${ }^{62}$

Here Cyril stated that because all humanity rose up to the person of Christ, he was called the last Adam. Just as Adam gave to humanity what was corrupt and dejected, so Christ gave all that was part of joy and glory. Christ is understood to be the second Adam because he gave 'to the common nature all things that belong to joy and glory'. The basis on which Christ is the second Adam is that he was a human being, just like Adam, and yet he was found to be sufficient where Adam was deficient. This represents a more processed Adam-Christ typology than Paul, but it remains unclear from this passage in what way the last Adam gave 'to the common nature all things that belong to joy and glory'.

60 Wilkin, Judaism, 102.

61 Wilkin, Judaism, 106.

62 Cyril of Alexandria, Joannem 1.9; P. E. Pusey and Thomas Randell, trans., Commentary on the Gospel according to St. John (3 vols.; Oxford: J. Parker, 187485): 1:141; P. E. Pusey, ed., Sancti Patris Nostri Cyrilli Archiepiscopi In D. Joannis

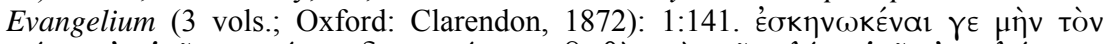

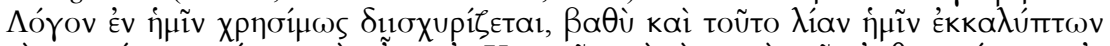

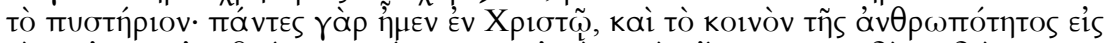

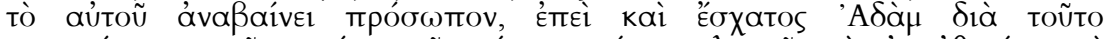

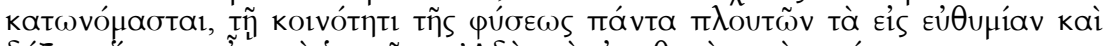

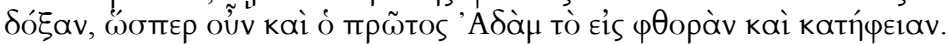


The second time the Adam-Christ typology appeared in Cyril's commentary is in his discussion of Jesus' statement in John 16:33: 'I have overcome the world!' He interpreted this statement to mean that just as Christ proved himself to be superior to sin and death, so those who attempt the struggle for his sake will be given his strength to overcome sin and death. He further stated:

For if He conquered as God, then it profited us nothing; but if as man, we are herein conquerors. For He is to us the Second Adam come from heaven, according to the Scripture. Just as then we have borne the image of the earthy, according to its likeness falling under the yoke of sin, so likewise also shall we bear the image of the heavenly, that is Christ, overcoming the power of sin and triumphing over all the tribulation of the world; for Christ has overcome the world. ${ }^{63}$

Here the Adam-Christ typology was used to explain how Christ's work of overcoming the world is transferred to believers. His quotation of 1 Corinthians 15:49 showed that he was clearly influenced by Paul. He understood 'we have borne the image of the earthy' to refer to falling into the bondage of sin, and 'so likewise also shall we bear the image of the heavenly' to refer to overcoming the world. Again, the typology was more polished than Paul's and so the actual points of correspondence were not stated explicitly. These will become clear when we look at two more examples.

A third occurrence of the Adam-Christ typology appeared in Cyril's comments on Jesus' trial before Pilate. Cyril equated Pilate with Satan and compared the statement by Pilate in John 19:4, 'I find no basis for a charge against him', with the fault Satan found in Adam. ${ }^{64} \mathrm{He}$ further expounded on this comparison with the primary comparison being Adam's one act of disobedience and Christ's life of obedience with their corresponding consequences for humanity. As was especially clear in Methodius, it is Christ's life of obedience, not his sacrificial death, which is compared with Adam's act of disobedience.

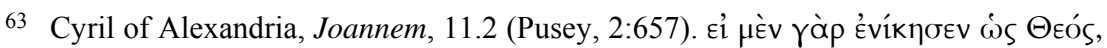

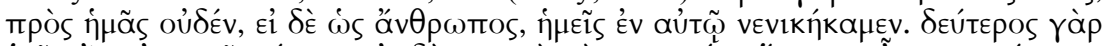

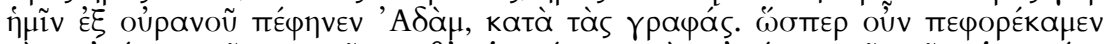

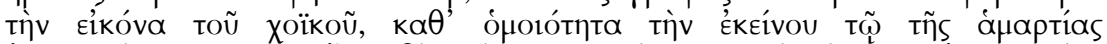

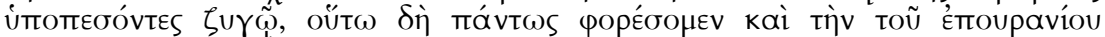

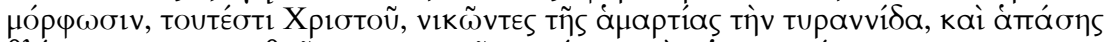

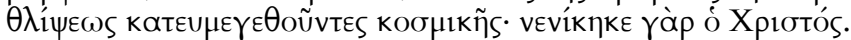

64 Cyril of Alexandria, Joannem, 12 (Pusey, 3:63). 
One final use of the Adam-Christ typology that is especially helpful was in Cyril's comments on Jesus' baptism. The numerous attempts by different church fathers to explain why Jesus was baptised show that this was a passage that caused many problems for the early church. ${ }^{65}$ Cyril developed a unique explanation with the help of the Adam-Christ typology. He began by stating that when God created Adam in the image and likeness of God he gave him his Holy Spirit, but when he sinned, God 'recalled the grace given him' ${ }^{66}$ Although humanity still had God's Spirit, the image of God was defaced because of the sin of Adam. Eventually, the Spirit departed completely, and man was left ignorant of God. God decided to return humanity to its original image by sending the second Adam, who met the requirements of the first Adam but was different because he was from heaven. Cyril wrote: ' $\mathrm{He}$ sends in our likeness his own son who is by nature without change or variation, who does not know sin, that as by the disobedience of the first we became subject to divine wrath, so that through the obedience of the second, we might both escape the curse and the evils from it might come to nothing. ${ }^{67}$ Wilkin noted that what was unique about Cyril's use here is that the second Adam is juxtaposed with Jesus as the Son of God rather than his humanity ${ }^{68}$ Apart from this instance, the Adam-Christ typology had always been a way of speaking of Jesus' humanity for Cyril. This passage makes it clear that, for Cyril, the Adam-Christ typology was only fulfilled because Jesus was both God and man. This also shows clear typological heightening. The difference between the first and second Adam is that the second came from heaven. Again, this is different from Christ as the one who was raised from the dead. It is Christ's pre-existence as the basis for his sinless life rather than his atoning death on the cross as the act that enabled him to be the second Adam.

65 Robert Wilkin, 'Exegesis and the History of Theology: Reflections on the AdamChrist Typology in Cyril of Alexandria', Church History 35 (June 1966): 137-56, esp. 146.

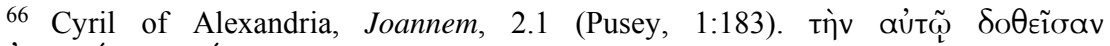

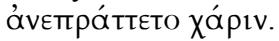

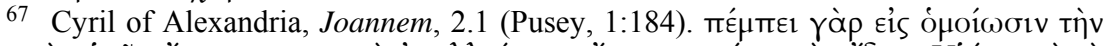

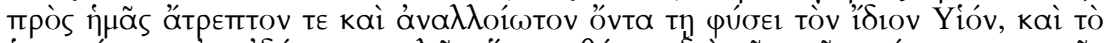

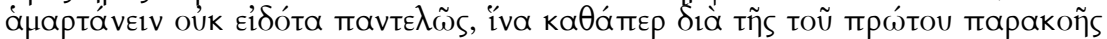

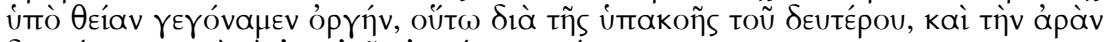

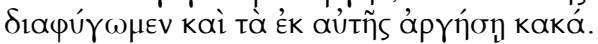

68 Wilkin, Exegesis, 150. 
Cyril, like Methodius, emphasised Christ's pre-existence and perfect life as the basis for the new humanity. This was seen most clearly in Cyril's discussion of Jesus' baptism. The advantage that Christ had over the first Adam was that he was the heavenly man, and therefore able to resist sin where Adam could not. This emphasis on Christ's preexistence was not perceptible in Paul's Adam-Christ typology. For Cyril, Christ's perfect life was the foundation on which the new humanity was built. Christ's resurrection still has value because it demonstrates the victory of Christ over death, but the consequence of this was that it reduced the theological significance of the death and resurrection of Jesus by placing greater emphasis on Jesus' perfect life.

\section{Conclusion}

This comparison has examined the use of the Adam-Christ typology in the early church. The development that has been traced was a shift away from Christ's death and resurrection and toward his pre-existence and sinlessness. Paul understood the correspondence between Christ and Adam to be that each was one man who did one act that had consequences for all humanity. Christ's obedience was his death on the cross. In Irenaeus, Hippolytus and Origen, an additional correspondence was found between the creation of Adam and Christ's virgin birth. In Methodius, this correspondence between the unique character of the birth of each, and their similar lives became the basis of the typology. The difference was that where Adam sinned, Christ did not. Further reflection on the Adam-Christ typology and the influence of other Scriptural passages expanded and transformed the Adam-Christ typology in ways not explicit in Paul.

In addition, this development away from Christ's death and resurrection and toward his perfect life deemphasises Paul's focus on the future resurrection which is always implicit and at times explicit. For Paul, the new humanity of which Christ is the progenitor is the future resurrected humanity. The emphasis is placed in the future in that those on earth are only part of this new humanity in so far as their future resurrection has been guaranteed. In this way the new race in Christ is much more 'concrete' (or will be). For the church fathers who find the correspondence in Christ's perfect life, the emphasis is on the way that Christians are changed into God's image on earth. This point 
is merely a difference in emphasis, for each person considered above would certainly accept both the bodily resurrection of the dead and the reality of transformation to the image of Christ in this life. For Paul, the way in which Christ is the progenitor of a new humanity is that he is the firstborn from among the dead and the new humanity are those who will be resurrected as he was. 